\title{
Esthetic restoration of malpositioned anterior teeth by tooth shape and gingival contour modification : a clinical report
}

\author{
Ja-Yeong Kim, Kyoung-A Kim², Jae-Min Seo ${ }^{3 *}$ \\ 'Department of Dentistry, Presbyterian Medical Center, University of Seonam College of Medicine, Jeonju, Republic of Korea \\ ${ }^{2}$ Department of Dentistry, School of Medicine, Eulji University, Daejeon, Republic of Korea \\ ${ }^{3}$ Department of Prosthodontics, School of Dentistry and Institute of Oral Bio-Science, Chonbuk National University, Jeonju, \\ Republic of Korea
}

In esthetic treatments, it is important to consider the arrangement of teeth and the relation between the teeth and soft tissues. A precise diagnosis and establishing an appropriate treatment plan is essential in an esthetic treatment of anterior maxillary teeth. For a fixed prosthesis to meet esthetic expectations, It is crucial to achieve symmetry and adequate proportions of the gingival contour around the crowns. To achieve an esthetic improvement and creating a favorable environment for gingival healing of a physiologic gingival contour, gingivectomy, crown lengthening and forced eruption can be applied to the appropriate site. All ceramics or porcelain laminate veneer can be selected for esthetic improvement of teeth contour and shade. In this case report, malposition of the remaining teeth made it hard to get an esthetic appearance. Gingivectomy, crown lengthening and provisional restoration insertion were performed before the final prosthesis fabrication to reform the gingival form. This case presents satisfying result esthetically and functionally. (J Dent Rehabil Appl Sci 2015;31(2):143-9)

Key words: malposition; gingivectomy; crown lengthening; all ceramics; laminate veneer

\section{서론}

최근 미에 대한 관심이 높아지면서 치아 성형 및 교정 에 대한 요구도가 증가하고 있다. 특히, 상악 전치부가 위 치나 배열 이상을 보이는 경우 이의 개선을 위해 내원하 는 환자들이 증가하였다. 위치 이상을 보이는 전치부 치 아는 치은 및 치아의 형태 또한 이상을 보이는 경우가 많 아 교정 치료를 통한 위치 개선과 함께 치은 성형과 심미 적 보철수복이 필요한 경우가 많다. 본 증례는 심미적 요 구도가 높은 젊은 여자 환자에서 위치 이상인 상악 전치 부를 교정 치료, 치은 성형, 심미적 보철치료를 시행함으

*Correspondence to: Jae-Min Seo

Assistant Professor, Department of Prosthodontics, School of Dentistry and Institute of Oral Bio-Science, Chonbuk National University, 664-14 Dukjin-Dong, Dukjin-Gu, Jeonju, 561-756, Repulic of Korea

Tel: +82-63-250-2696, Fax: +82-63-250-2218, E-mail: jmseo@jbnu.ac.kr

Received: April 2, 2015/Last Revision: May 5, 2015/Accepted: May 31, 2015
로써 기능과 심미적으로 만족할 만한 성과를 얻었기에 이를 보고하고자 한다.

\section{증례 보고}

\section{1. 증례 1}

본 환자는 19세의 여자 환자로 상악 전치부의 심미적 개선을 위해 내원하였다. 임상 검사 및 방사선 검사 결 과 \#11 치아는 상실되어 있었으며 \#12, 21, 22치아 사이 에는 공간이 존재했다. \#12,13치아가 좌측으로 이동되

Copyright@ 2015 The Korean Academy of Stomatognathic Function and Occlusion. (c) It is identical to Creative Commons Non-Commercial License. 

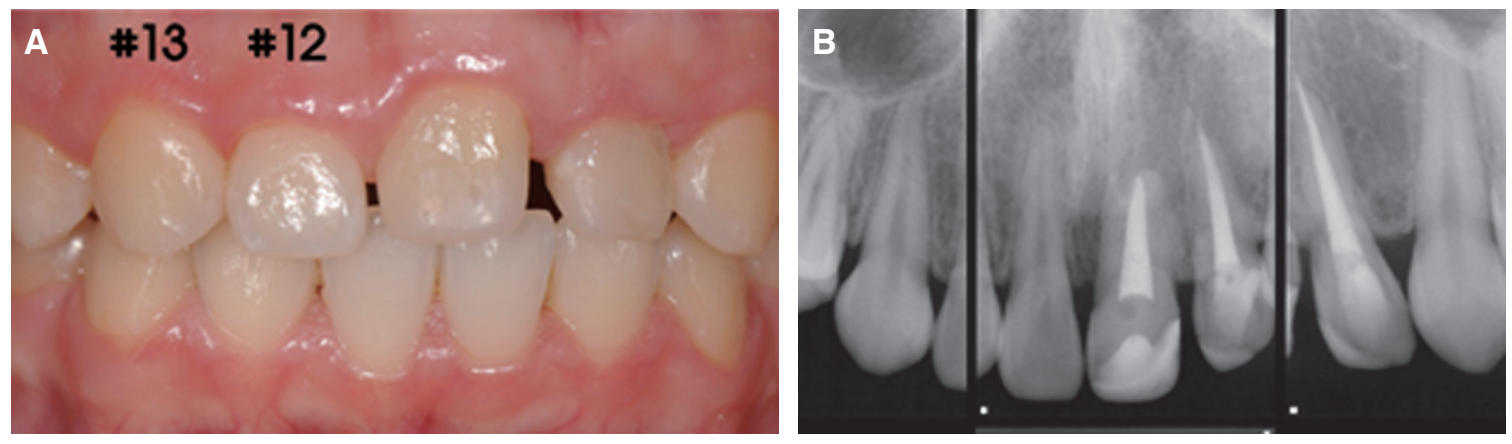

Fig. 1. Clinical examination. (A) Initial intraoral photo image, (B) Periapical standard radiographic image.

어 \#11,12 치아 자리 쪽으로 치우쳐 위치하고 있었으며 $\# 12,22$ 치아의 치은연이 주변치아보다 하방에 위치하 였고 특히, \#12과 \#21 치아간 치은연의 부조화가 심한 상태였다(Fig. 1).

수 년 전 교통사고로 \#11치아는 상실되었고 탈구되고 파절된 \#21, 22 치아는 근관 치료와 교정 치료를 받은 병력이 있었다. 검사 결과 \#21, 22치아는 골유착된 상태 로 추가적인 교정 치료를 통한 치아 이동은 불가능하였 다. 진단 모형의 삭제를 통해 치은연의 부조화를 수정하 고 왁스 업을 시행한 결과 \#12, 22치아의 치은 성형을 시행한 후 \#13치아를 측절치 형태로, \#12치아를 중절 치 형태로 보철물을 제작하면 심미적 회복이 가능하리 라 판단되었다(Fig. 2). 따라서 보철 치료 전에 $3 \mathrm{~mm}$ 미 만의 치주낭을 가지고 있는 \#12, 22 치아는 골삭제를 동 반한 치관연장술을 시행한 후 ${ }^{1}$, 많은 치질 손상이 발생 한 \#12, 21, 22 치아는 완전도재관으로, 단순한 형태수 정만이 요구되는 \#13 치아는 도재 라미네이트로 보철 수복을 계획하였다.

먼저 \#12, 22 치아에 $2 \mathrm{~mm}$ 높이의 치조골 삭제를 동 반한 치관연장술을 시행하였다(Fig. 3).

치관연장술을 시행하고 2주가 지난 후에 \#13, 12, 21, 22 치아의 초기 삭제를 시행하고 임시 보철물을 제작하 였다. 측절치의 임시 보철물을 더 큰 중절치 형태로 만 들기 위해 근심 및 순측에 치은연하 마무리선을 부여하 였고 여기서부터 시작하는 최종 보철물의 근심 및 순측 의 치경부 형태를 가공치처럼 넓게 형성함으로써 치경 부 출현각(emergence profile)이 중절치와 유사하도록 제작하였다(Fig. 4). 외과적 수술 및 급격한 치경부 출현 각으로의 변화로 인한 치주조직의 반응을 관찰하기 위

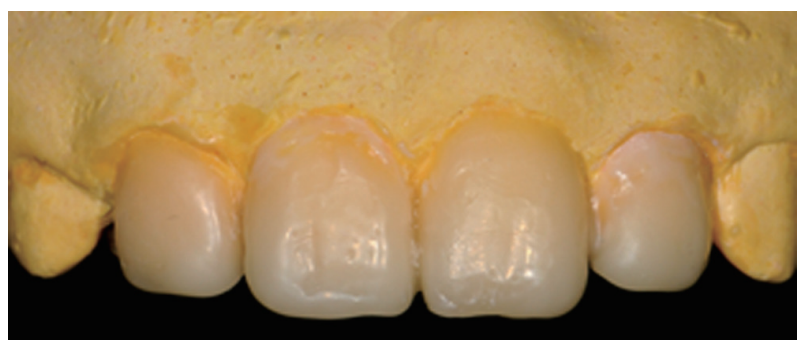

Fig. 2. Crown lengthening on the diagnostic cast (\#12, 22 teeth) \& diagnostic wax-up.

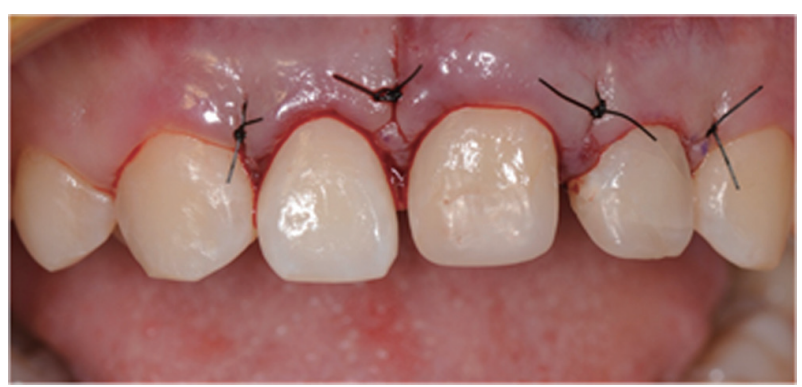

Fig. 3. Crown lengthening on \#12, 22 teeth.

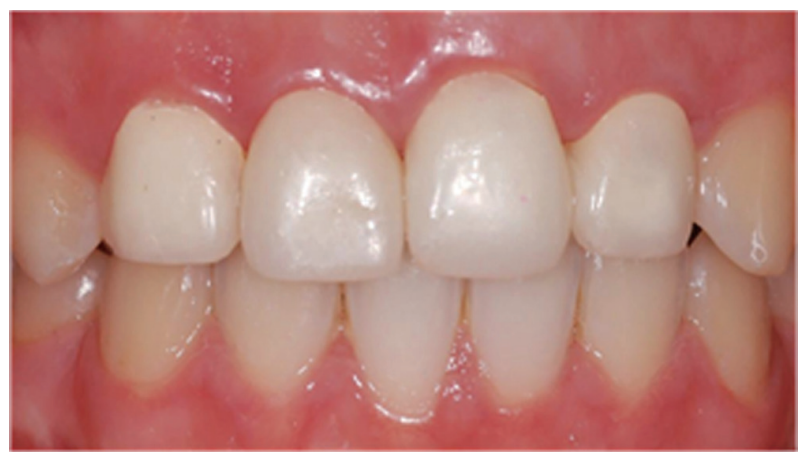

Fig. 4. Provisional restoration setting. 

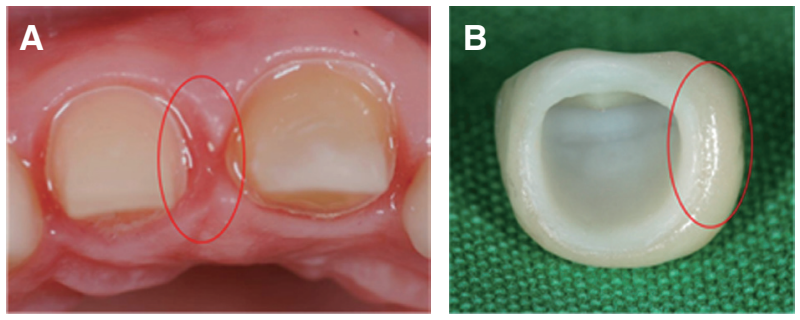

Fig. 5. Final prosthesis fabrication. (A) Molded gingival contour by provisional restoration, (B) Mesio-cervical part of the final prosthesis on \#12 tooth.

해 10 주 동안 임시 보철물 상태를 주기적으로 점검하고 수정하였으며 그 결과 치은의 염증이나 치태 축적, 치은 증식 등의 특이소견 없이 치은 형태 및 상태가 안정되었 다.

따라서 최종 보철물을 위한 최종 삭제와 인상을 채 득하였다. 최종 보철물 장착 전 \#12치아의 치은(특히, 근심측)은 임시 보철물의 형태와 치경부 출현각에 따 라 매우 안정되어 있었다(Fig. $5 \mathrm{~A}$ ). 형성된 치은의 형태 를 최대한 변형 없이 인기하기 위해 임시 보철물을 제 거하고 최대한 빠른 시간에서 흐름성이 좋은 실리콘 인 상재(Aquasil XLV, Dentsply, Milford, USA)를 이용하 여 인상채득하였다. \#12, 21, 22 치아에는 통법에 따라 제작된 완전도재관(IPS e.max Press, Ivoclar Vivadent, Schaan, Liechtenstein)을 이중중합형 레진시멘트 (RelyX Ultimate, 3M ESPE, Seefeld, Germany)를 이용 해 접착하고 \#13치아에는 도재 라미네이트 베니어를 광중합형 레진시멘트(RelyX Veneer, 3M ESPE, Seefeld, Germany)로 접착하였다(Fig. 6).

\section{2. 증례 2}

본 환자는 19세의 여자 환자로 상악 전치부의 심미 적 문제를 주소로 내원하였다. 약 3년 전 \#13, 23치아가 \#11, 21 치아 위치로 이소 맹출되어 치근 흡수된 \#11, 21 을 발치하고 \#13, 23치아의 교정적 정출술을 시행하 였다(Fig. 7). 그 결과 \#13, 23 치아가 \#11, 21치아 위치 에 배열되었으며 교정과 및 보철과 의사가 긴밀한 협진 을 통하여 정확한 위치에 4전치가 위치될 수 있도록 하 였다. 하지만 왜소치(peg lateralis)인 \#12치아를 비롯하 여 상악 4 전치의 치관 형태가 비정상적이었으며 치아

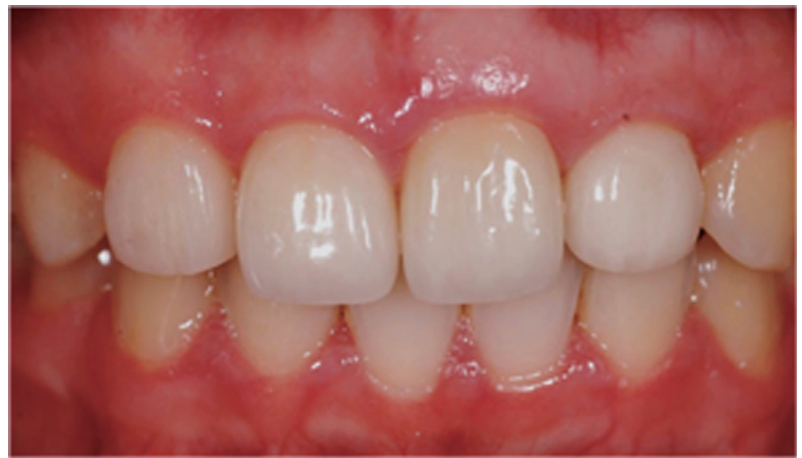

Fig. 6. Final prosthesis setting.

사이 공간이 존재하였고 \#11, 21 치아 위치에 있는 \#13, 23 치아간 치은연의 부조화가 있었다(Fig. 8).

진단 모형을 제작하고 모형상에서 \#13 치아의 치은연 을 삭제하여 연조직의 부조화를 수정한 후 진단 왁스 업 을 시행하였다(Fig. 9). 그 결과 \#13치아의 치은 성형 후 \#13, 23 치아는 완전도재관으로, \#12, 22 치아는 도재 라미네이트 베니어로 보철수복을 계획하였다. \#13, 23 치아는 심미적인 측면에서의 순면의 형태 변화 뿐 아니 라, 전방유도를 담당할 설면의 형태의 재설정이 필요하 였고 전방유도시 보철물의 파절저항 및 유지력이 요구 된다고 판단하였기에 라미네이트 베니어가 아닌 완전도 재관을 계획하였다.

$4 \mathrm{~mm}$ 정도의 치주낭을 보이는 \#13치아를 골 삭제 없 이 약 $1 \mathrm{~mm}$ 의 치은 절제하였다. 곧바로 상악 4전치의 초기 삭제를 시행하고 임시 보철물을 장착하였다(Fig. 10).

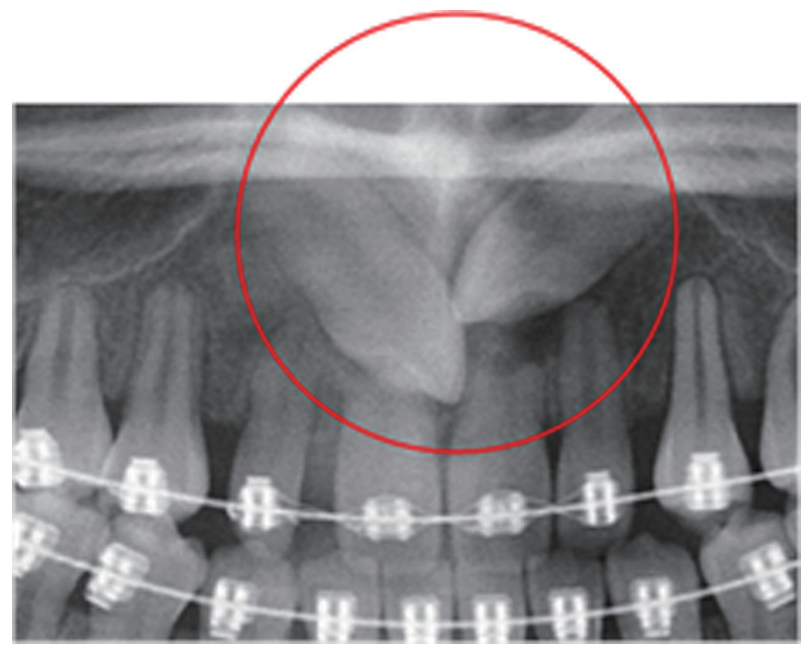

Fig. 7. Panoramic radiographic image. 

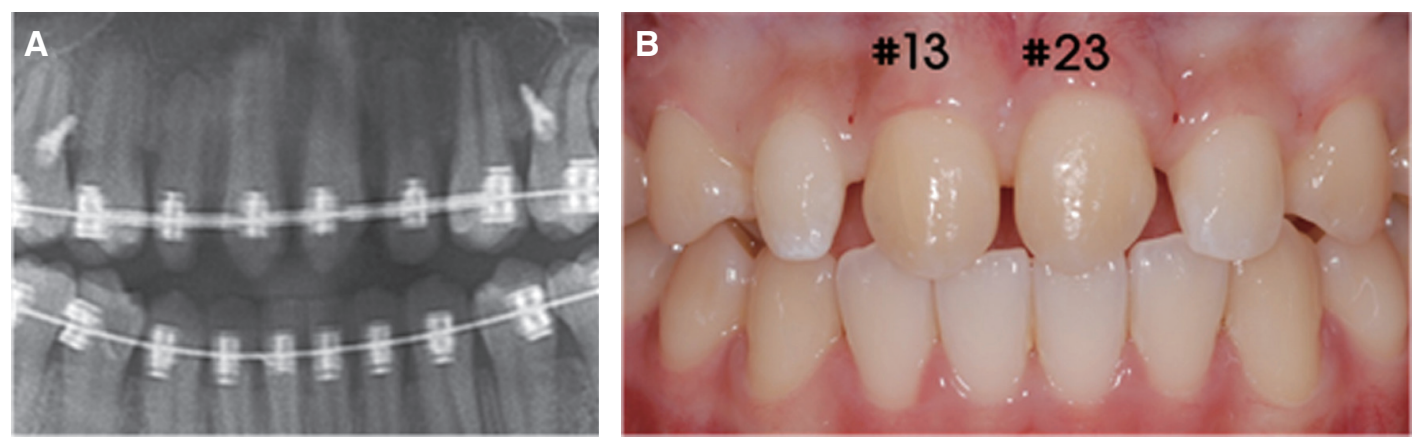

Fig. 8. After orthodontic treatment : \#11, 21 teeth were extracted, \#13, 23 teeth were moved to the \#11, 21 teeth site by orthodontic forced eruption. (A) Panoramic radiographic image, (B) Intraoral photo image.

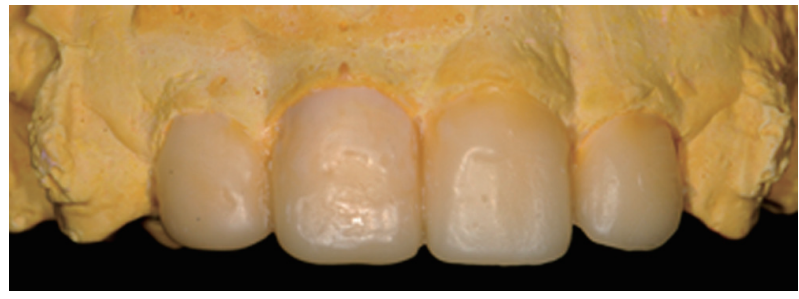

Fig. 9. Gingivectomy on the diagnostic cast (\#13 teeth) \& diagnostic wax-up.
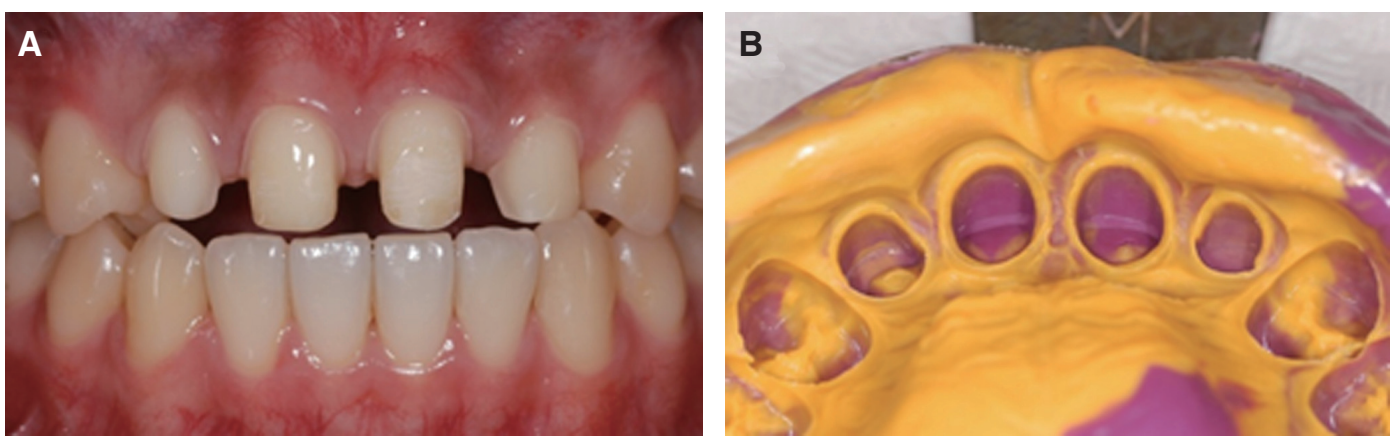

Fig. 11. Final preparation $(A)$ and impression taking (B).

6주간 관찰 후 치은의 안정을 확인하고 최종 치아 형 성 및 인상을 채득하였다(Fig. 11).

\#13, 23 치아에는 완전도재관(IPS e.max Press)을 이 중중합형 레진시멘트(RelyX Ultimate)를 이용해 접착하 고 \#12, 22치아에는 도재 라미네이트 베니어를 광중합 형 레진시멘트(RelyX Veneer)를 이용해 접착하였다(Fig. 12).

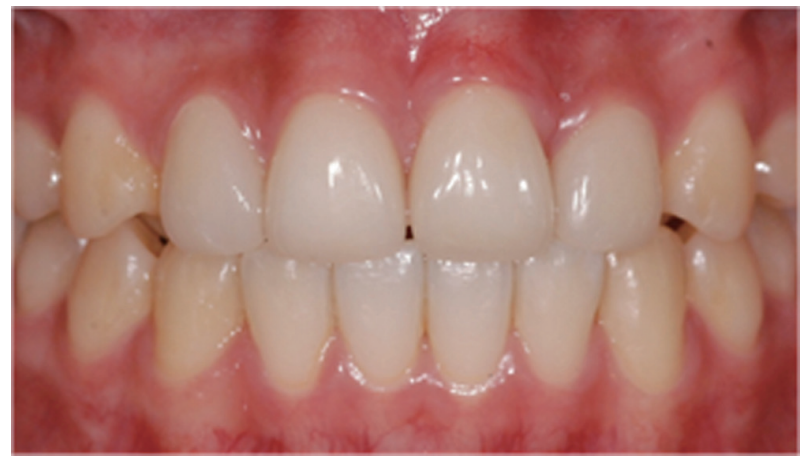

Fig. 12. Final prosthesis setting. 


\section{고찰}

위치이상 상악 전치부는 대부분 교정 치료를 통해 심 미적으로 회복될 수 있다. 그러나 상기 임상 증례들처 럼 유착되어 치아 이동이 불가능하거나 교정 치료 후에 치아 상실 부위를 다른 치아가 대체하고 있다면 최종적 으로 보철 치료의 도움을 받아야만 한다. 첫 번째 증례 에서는 우측 중절치가 유년기에 후천적으로 결손되었 고 성장 및 교정치료에 의해 측절치가 중절치 위치로 이 동하였으나 치은연의 부조화 및 치관의 형태 이상, 치간 공간 등의 문제가 남아있었다. 이를 골삭제를 동반한 치 관연장술 후 완전도재관과 도재 라미네이트를 이용한 심미보철수복으로 해결하였다. 진단모형상에서 치은연 의 부조화를 해결하기 위해서는 $2 \mathrm{~mm}$ 의 치은절제가 필 요하였으며 술 전 치주낭 검사에서 $3 \mathrm{~mm}$ 의 치주낭이 존재하였기 때문에 생물학적 폭경을 확보하기 위해 골 삭제를 동반해야 했다. ${ }^{1}$ 치관연장술을 시행하였거나 크 기가 작은 치아를 더 큰 치관의 형태로 수정해야 하는 경우의 보철물 제작시에는 치경부 출현각 설정이 어려 울 수 있다. 그 이유는 치근의 모양이 근단부로 갈수록 좁아지는 원추형이고 치근과 최종 보철 치관 간의 크기 차이가 심해지기 때문이다. 이 증례에서는 측절치를 더 큰 중절치 형태로 수복하기 위해 근심 및 순측에 치은연 하 마무리선을 부여하였고 여기서부터 시작하는 최종 보철물의 형태를 가공치처럼 넓고 급격한 경사로 형성 하였으며 그 결과 중절치와 유사한 치경부 형태를 가지 게 되었다. Koidis 등은 구강 위생관리를 위해서는 직선 형으로 치경부출현각을 부여해야 한다고 했다. 따라서 면밀한 구강위생관리교육을 하고 이 형태를 가진 임시 보철물을 장기간 사용하면서 치태관리능력 및 하방의 치주 상태에 대해 주의 깊은 관찰을 하였다. 그 결과 특 이소견 없이 양호하여 임시 보철물에 의해 형성된 치은 의 형태를 변형 없이 인기하기 위해 임시 보철물을 제거 한 후 짧은 시간 내에 흐름성이 좋은 인상재를 이용하여 최종인상을 채득하고 이에 맞는 완전도재관을 제작하였 다. 지속적인 정기 검진을 통하여 평가 및 관리가 필요 할 것으로 사료된다. 반면에 상악 우측 견치는 도재 라 미네이트 베니어를 이용해 더 작은 측절치 형태로 보철 수복하였는데 이를 위하여 근심인접면의 삭제량을 높이 고 작은 치경부 출현각을 부여한 도재 라미네이트 베니 어를 제작하였다. 도재 라미네이트 베니어는 심미성뿐 아니라 치질의 보존, 색상 안정성이 매우 우수하며 법랑
질 접착 술식의 향상 등으로 성공률 또한 높아서 15년간 $93 \%$ 까지 보고되고 있다. ${ }^{3}$

상악에서 견치와 중절치의 매복은 자주 볼 수 있다. 특 히 견치의 매복은 유병율이 $2 \%$ 정도라고 알려져 있다. ${ }^{4}$ 견치 매복의 원인은 긴 맹출 경로, 치아-악궁 크기 부조 화, 치배 위치 이상, 유치 만기 잔존 혹은 조기 탈락, 외 상, 유착 등으로 매우 다양하다. ${ }^{5,6}$ 견치가 매복된 경우 인접치의 변위, 악궁 장경의 감소, 매복된 치아의 내흡 수, 치성 낭종의 형성, 인접치의 치근 흡수, 감염 등의 문 제가 발생할 수 있는데, ${ }^{7}$ 두 번째 증례에서도 매복된 상 악 견치로 인해 중절치의 치근 흡수가 일어나 상악 양측 중절치를 발거하게 되었다. 따라서 매복된 상악 견치를 교정적으로 중절치 위치로 정출시켰으며 보철과 의사는 교정 치료 중간에 진단모형을 통해 주기적인 공간을 분 석함으로써 정확한 위치에 상악 4전치가 위치될 수 있 도록 교정과 의사와 긴밀하게 협진하였다. 따라서 치은 연을 수정하고 상악 4전치를 완전도재관과 도재 라미네 이트 베니어로 보철수복함으로써 심미적으로 회복할 수 있었다.

본 증례들은 위치 이상을 보이는 상악 전치부에서 정 확한 진단 및 치료계획을 통한 교정 치료 및 치은 성형, 보철 치료를 통하여 기능적 심미적으로 만족할 만한 결 과를 얻을 수 있음을 보여준다.

\section{결론}

위치 이상을 보이는 상악 전치부를 회복하기 위해서 는 교정 치료가 첫 번째로 고려해야 할 치료 방법이다. 그러나 본 증례들과 같이 교정 치료가 불가능하거나 교 정 치료만으로 심미적 기능적 회복에 한계가 있는 경우 에는 긴밀한 협진을 통하여 연,경조직의 조화를 고려한 보철 치료를 시행함으로써 우수한 심미적 결과를 얻을 수 있다.

\section{Orcid}

Jae-Min Seo http://orcid.org/0000-0001-5095-4046

\section{References}

1. Assif D, Pilo R, Marshak B. Restoring teeth following crown lengthening procedures. J Prosthet Dent 
1991;65:62-4.

2. Koidis PT, Burch JG, Melfi RC. Clinical crown contours: contemporary view. J Am Dent Assoc 1987; 114:792-5.

3. Friedman MJ. A 15-year review of porcelain veneer failure: a clinician's observations. Compend Contin Educ Dent 1998;19:625-8, 630, 632 passim; quiz 638.

4. Ericson S, Kurol J. Longitudinal study and analysis of clinical supervision of maxillary canine eruption. Community Dent Oral Epidemiol 1986;14:172-6.
5. Brin I, Becker A, Shalhav M. Position of the maxillary permanent canine in relation to anomalous or missing lateral incisors: a population study. Eur J Orthod 1986;8:12-6.

6. Zilberman Y, Cohen B, Becker A. Familial trends in palatal canines, anomalous lateral incisors, and related phenomena. Eur J Orthod 1990;12:135-9.

7. Shafer WG, Hine MK, Levy BM. A text book or oral pathology. $2^{\text {nd }}$ ed. Philadelphia; WB Saunders; 1963. p. 2-75. 


\section{위치이상 치아의 치은 성형을 동반한 심미적 보철수복}

\section{김자영 ${ }^{1}$, 김경아 ${ }^{2}$, 서재민 ${ }^{3 *}$}

${ }^{1}$ 서남대학교 의과대학 예수병원 치과학교실

${ }^{2}$ 을지대학교 의과대학 치과학교실

${ }^{3}$ 전북대학교 치의학전문대학원 치과보철학교실 및 구강생체과학연구소

전치부는 심미적인 관점에서 치열 및 연조직과의 조화가 매우 중요하다. 상악 전치부의 심미적인 치료는 술 전 정확한 진단과 치료계획이 필수적인데 술자는 특히 치관부 크기의 적절한 비율과 치은 형태의 대칭에 대해 충분히 고려해야 한다. 만약 치은의 형태가 비심적이고 부자연스러운 경우에는 치은 절제술, 골삭제를 동반한 치관 연장술, 교정적 정출 술 등을 시행할 수 있다. 치관의 형태 및 위치가 부적절한 경우에는 술 전 진단 모형 및 왁스 업을 통해 교정 치료나 완 전도재관, 라미네이트 베니어 등의 심미적 보철치료를 계획할 수 있다. 본 증례들에서는 치아의 위치 이상과 연,경조직 의 부조화를 가진 전치부를 교정 치료 및 치은 성형과 심미적 보철 치료를 시행함으로써 만족할만한 결과를 얻었기에 이를 보고하고자 한다.

(구강회복응용과학지 2015;31 (2):143-9)

주요어: 위치이상; 치은절제술; 치관연장술; 완전도재관; 라미네이트 